\title{
Traditional medicinal plant knowledge and use by local healers in Sekoru District, Jimma Zone, Southwestern Ethiopia Haile Yineger* and Delenasaw Yewhalaw
}

\author{
Address: Department of Biology, Jimma University, P.O.Box 5195, Jimma, Ethiopia \\ Email: Haile Yineger* - haile_mulu@yahoo.com; Delenasaw Yewhalaw - delenasawye@yahoo.com \\ * Corresponding author
}

Published: 4 June 2007

Journal of Ethnobiology and Ethnomedicine 2007, 3:24 doi:10.1/86/1746-4269-3-24

This article is available from: http://www.ethnobiomed.com/content/3/I/24

(c) 2007 Yineger and Yewhalaw; licensee BioMed Central Ltd.

This is an Open Access article distributed under the terms of the Creative Commons Attribution License (http://creativecommons.org/licenses/by/2.0), which permits unrestricted use, distribution, and reproduction in any medium, provided the original work is properly cited.
Received: 2 January 2007

Accepted: 4 June 2007

\begin{abstract}
The knowledge and use of medicinal plant species by traditional healers was investigated in Sekoru District, Jimma Zone, Southwestern Ethiopia from December 2005 to November 2006. Traditional healers of the study area were selected randomly and interviewed with the help of translators to gather information on the knowledge and use of medicinal plants used as a remedy for human ailments in the study area. In the current study, it was reported that 27 plant species belonging to 27 genera and 18 families were commonly used to treat various human ailments. Most of these species $(85.71 \%)$ were wild and harvested mainly for their leaves $(64.52 \%)$. The most cited ethnomedicinal plant species was Alysicarpus quartinianus A. Rich., whose roots and leaves were reported by traditional healers to be crushed in fresh and applied as a lotion on the lesions of patients of Abiato (Shererit). No significant correlation was observed between the age of traditional healers and the number of species reported and the indigenous knowledge transfer was found to be similar. More than one medicinal plant species were used more frequently than the use of a single species for remedy preparations. Plant parts used for remedy preparations showed significant difference with medicinal plant species abundance in the study area.
\end{abstract}

\section{Background}

Traditional medicine has remained as the most affordable and easily accessible source of treatment in the primary healthcare system of resource poor communities and the local therapy is the only means of medical treatment for such communities.

In Ethiopia, medicinal plants have been used as traditional medicine to treat different human ailments by the local people from time immemorial. These medicinal plants are estimated to be over 700 species [1] and most of them are confined to the southwestern regions of the country [2].
There is a high expectation of enormous traditional knowledge and use of medicinal plant species in Ethiopia due to the existence of diverse cultures, languages and beliefs among the people. However, since cultural systems are dynamic [3], the skills are fragile and easily forgettable as most of the indigenous knowledge transfer in the country is based on oral transmission [4]. To our knowledge, there are no data regarding the traditional medicinal plant knowledge and use by the local communities in Sekoru District, Southwestern Ethiopia. Therefore, the current study was conducted to assess and document the indigenous knowledge and use of medicinal plant species by traditional healers to treat human ailments in the study area. 


\section{Methods \\ Study area}

The study was conducted in four Kebeles (the smallest administrative units in Ethiopia) of Sekoru District, Jimma Zone, Southwestern Ethiopia from December 2005 to November 2006. The four selected Kebeles were Unquuree, Ganda Chala, Liben and Bore (Figure 1). These areas lie at an altitudinal range of $1693 \mathrm{~m}-1740 \mathrm{~m}$ a.s.l. The study area has a dry and hot climate with a mean annual temperature of $19.2^{\circ} \mathrm{C}$ and annual rainfall that varies from $1300 \mathrm{~mm}-1800 \mathrm{~mm}$. Clay soil with a thin layer of humus top soil is the main soil type over the area and evergreen montane thickets and shrubs are characteristic vegetation types of the area. The socioeconomic activity of the local population is mainly mixed farming which involves both cultivation of crops and rearing of livestock. Zea mays L., Sorghum bicolor (L.) Moench and Eragrostis tef (Zucc.) Trotter are the major crops cultivated in the area.

\section{Data collection}

An ethnobotanical study was conducted on four selected Kebeles of Sekoru District, Jimma Zone, Southwestern Ethiopia from December 2005 to November 2006. The coordinates of study Kebeles were recorded using a hand

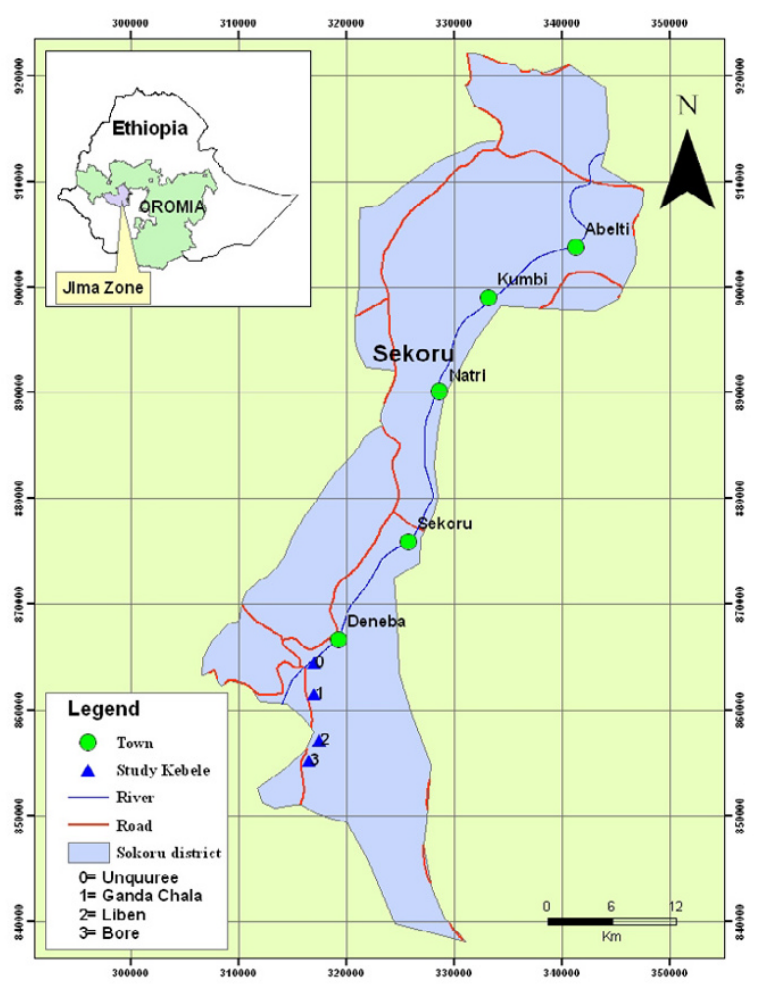

Figure I

Map showing location of the study sites. held GPS unit. Ethnobotanical data were collected from 13 randomly selected traditional healers using semi structured interviews and participant observations following [5]. The traditional healers involved in the study were all males and their ages ranged from 30 to 84 . Most of the healers were illiterate (53.85\%) and at most only able to read and write (30.77\%) while few (15.38\%) attended up to standard 4. Ethical clearance was sought from Jimma University Ethics Review Committee while verbal informed consent was obtained from each individual traditional healer who was participating during the study period.

Interviews were made with each traditional healer about the knowledge and use of medicinal plant species used to treat human diseases in the study area. The healers were professional practitioners who medicate the local people by using ethnomedicinal plants and their products. The interviews were facilitated with translators who were well conversant of the local language (Oromiffa). Data on human ailments treated, local name of plants used, growth form, degree of management (wild/cultivated), parts used, methods of preparation, route of administration and application, added values of medicinal plants, existing threats to medicinal plant species and indigenous knowledge transfer were recorded. The authors accompanied the traditional healers and translators and made field visits to observe and collect medicinal plant species reported to treat ailments. Voucher specimens of each medicinal plant species were also collected during the field visits and allotted collection numbers. The collected specimens were then dried, identified and deposited at Jimma University Regional Herbarium and at the National Herbarium, ETH (Addis Ababa University). The specimens were identified using herbarium materials, experts, and taxonomic keys in the various volumes of the Flora of Ethiopia and Eritrea [6-12].

\section{Data analysis}

Binomial test, chi-square $\left(\mathrm{X}^{2}\right)$ test and the Spearman rank correlation test were run in SPSS 12.0.1 to analyze ethnobotanical data. The Spearman rank correlation test was used to determine the correlation of the indigenous plant use knowledge with the age of traditional healers and their level of education whereas chi-square test was used to determine whether there was a significant variation on the abundance of traditional medicinal plant species with regard to their parts used, degree of management (wild/ cultivated), marketability and added values. Moreover, binomial test was employed to evaluate whether remedies were prepared from single species, healers had good knowledge of dosages, traditional medicines had adverse effects, marketable species were more frequently used, and whether healers used to transfer their indigenous 
knowledge. MS Excel Spreadsheet was also utilized for drawing bar graphs and to determine proportions.

\section{Results}

Traditional healers of the study area were found to play great roles in the primary healthcare systems of the local people as they were treating resource poor people who had little access and couldn't afford the cost for modern medications. They also reported that the local people have been seeking for their treatment even in preference to modern medications and also in connection with the community's belief that they would not get better medications for some of the diseases in modern health services. Moreover, the traditional healers indicated that they served the community best as the distribution of health services was limited in the study area.

No significant (Spearman correlation test, $r=0.140, \alpha=$ $0.05, \mathrm{p}=0.365$ ) correlation was observed between the age of traditional healers and the number of species reported by the healers. Moreover, the Spearman correlation test did not demonstrate significant (Spearman correlation test, $\mathrm{r}=0.258, \alpha=0.05, \mathrm{p}=0.091$ ) correlation between the educational level of traditional healers and the number of species reported. The response of the traditional healers with regard to their indigenous knowledge transfer was similar (binomial test, $\mathrm{p}=0.880$ ) in that some of them reported to transfer it to selected family members while some did not transfer it at all.

Altogether, seventeen human diseases or ailments were identified by the traditional healers of the study area. Twenty seven traditional medicinal plant species distributed among 27 genera and 18 botanical families were also cited by the traditional healers to treat those ailments (see Additional file 1). Fabaceae was the most represented family in terms of medicinal plant species diversity followed by Acanthaceae, Cucurbitaceae, Lamiaceae, Loranthaceae, Myrsinaceae and Verbenaceae.

Among the cited medicinal plant species of the study area, the majority $(85.71 \%)$ were wild. Whereas $10.71 \%$ of the reported medicinal plant species were both cultivated and wild. Few species $(3.57 \%)$ were indicated as cultivated. Moreover, significant $\left(\chi^{2}=24.080, \mathrm{df}=12, \alpha=0.05, \mathrm{p}=\right.$ 0.020 ) difference was observed between the degree of management (wild/cultivated) and abundance of the medicinal species in the area. The dominant growth forms among the reported medicinal plant species were shrubs $(37.04 \%)$ and trees $(25.93 \%)$. The proportion of the remaining growth forms was similar $(7.41 \%)$.

Most of the species (64.52\%) were harvested for their leaves to prepare remedies. Preparation of remedies from the roots of some $(19.35 \%)$ medicinal plant species was also reported by traditional healers of the study area. Plant parts used for remedy preparations also showed significant $\left(\chi^{2}=70.158, \mathrm{df}=36, \alpha=0.05, \mathrm{p}=0.001\right)$ difference with medicinal plant species abundance in the study area. About $64.52 \%$ of the medicinal species were cited to be used in fresh form in remedy preparations. Relatively few medicinal plant species were reported to be used in dried $(19.35 \%)$ and fresh or dried (16.13\%) forms.

The principal methods of remedy preparation were reported to be through crushing $(37.31 \%)$, squeezing $(29.85 \%)$ and powdering $(16.42 \%)$ of the various parts of medicinal plants (Figure 2). Additives like sugar, honey, tea, coffee, edible oil and garlic were used in most (60\%) of the remedy preparations. Moreover, more than one medicinal plant species were used more frequently (binomial test, $\mathrm{p}=0.000$ ) than the use of a single species for remedy preparations. Remedies for tumor (Tanachaa) were reported to be prepared by crushing fresh leaves of Tapinanthus globiferus (A. Rich.) Tiegh. and mixed with cold water to be administered orally. The powdered dry root of Gloriosa superba L. was administered orally along with tea and coffee to treat this ailment. Similarly, powdered root of Plumbago zeylanica L. was reported to be

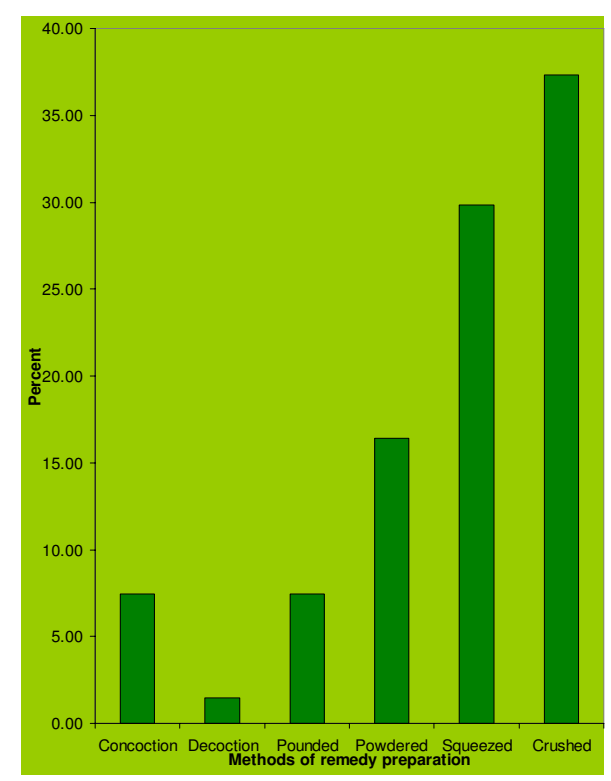

\section{Figure 2}

Methods used by traditional healers in remedy preparation. 
mixed with water and sugar and tumor patients drank half cup of the preparation for three days. Twigs of this species were also indicated to be put on the neck of patients as necklace and this was believed by traditional healers to cure the ailment. Freshly crushed roots of G. superba and Clerodendrum myricoides (Hochst) R. Br. ex Vatke were indicated to be squeezed with water and drunk against this ailment.

Healers used freshly crushed fruits of Gardenia ternifolia Schumach. \& Thonn. to treat haemorrhoids lesions. The dried fruits of this species were alternatively powdered and directly applied over infected sites of patients of this disease.

Fresh leaves of Calpurnia aurea (Ait.) Benth., Clematis hirsuta Perr. \& Guill., Engleriana woodfordioides (Schweinf.), Myrica salicifolia Hochst. ex A. Rich. and Plectranthus rupestris Vatke ex Baker were crushed, squeezed and a small amount of the juice was applied through auricular route for two days to treat earache (Dhukuba Guraa).

Juice prepared from pounded and squeezed fresh leaves of Croton macrostachyus Del., Premna schimperi Engl. and Vernonia amygdalina Del. were applied as a lotion on the lesions of patients of Abiato (Shererit). The remnant was also reported to be dried, powdered and applied over the lesions. Roots and leaves of Alysicarpus quartinianus A. Rich. were also crushed in fresh and put on the lesions of the patients.

Leaves of A. quartinianus, Clausena anisata (Willd.) Hook. f. ex Benth., M. salicifolia, Myrsine africana L. and P. schimperi were reported to be crushed and squeezed in fresh form with water. The juice was then indicated to be drunk in very small amount for three days to treat Naqarsaa.

Fresh roots of Entada abyssinica Steud. ex A. Rich., Momordica foetida Schumach. and Oreosyce africana Hook. f. were crushed and squeezed with water. The filtrate was reported to be given through hypodermal injection using a syringe to treat gonorrhoea (Dhukuba Dhiraa).

Remedies were reported to be administered mainly through oral $(45.45 \%)$, dermal $(33.33 \%)$ and auricular $(15.15 \%)$ routes (Figure 3$)$. However, knowledge of traditional healers on dosage of each remedy was poor (binomial test, $p=0.004$ ). The absence of any adverse effects of traditional medicines after administration were also more frequently mentioned (binomial test, $\mathrm{p}=0.008$ ) by the traditional healers but some of the preparations were reported to have some adverse effects like vomiting and temporary inflammations on patients. Interestingly, all of the traditional healers indicated that they did not use antidotes for the adverse effects of traditional medicines.

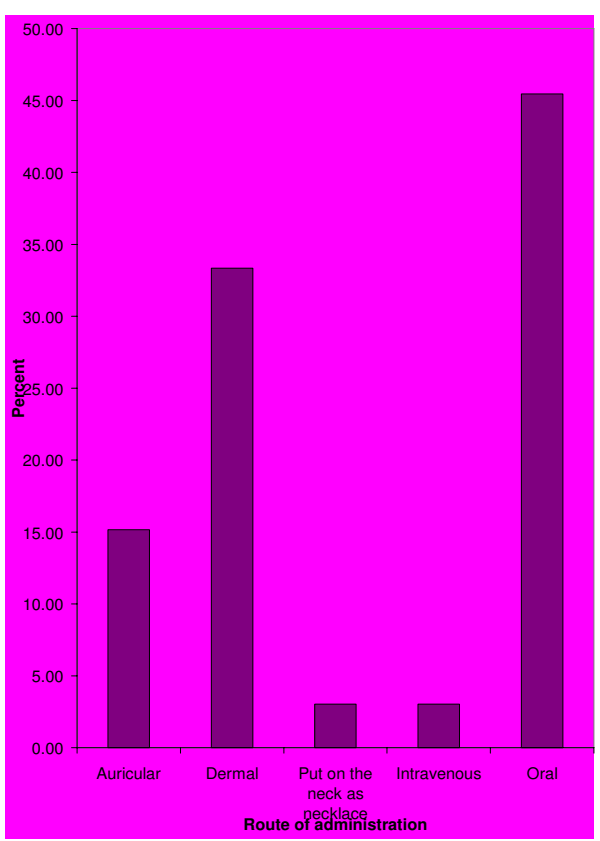

Figure 3

Route of traditional medicine administrations.

The most cited modes of remedy applications were drinking $(42.86 \%)$, topical applications $(28.57 \%)$ and dropping $(14.29 \%)$.

Non-marketable medicinal species were more significantly cited (binomial test, $\mathrm{p}=0.000$ ) by the traditional healers. The abundance of marketable and non-marketable medicinal plant species were significantly $\left(\chi^{2}=\right.$ $46.728, \mathrm{df}=8, \alpha=0.05, \mathrm{p}=0.000$ ) varied. The majority of the recorded medicinal species were reported as abundant $(36.67 \%)$ and rare (33.33\%). Some species were also mentioned as very abundant $(16.67 \%)$ and very rare (13.33\%). The abundance of reported medicinal plant species also showed significant $\left(\chi^{2}=34.824, \mathrm{df}=8, \alpha=\right.$ $0.05, p=0.000$ ) variation with their added values. Most of the medicinal plant species were reported to have added values to the local people. The most cited uses were firewood $(36.11 \%)$, forage $(22.22 \%)$ and construction (13.89\%). Some species (16.67\%) had no uses other than their medicinal value (Figure 4).

The most mentioned threats to medicinal plants of the study area were deforestation (40\%), drought (17.5\%) 


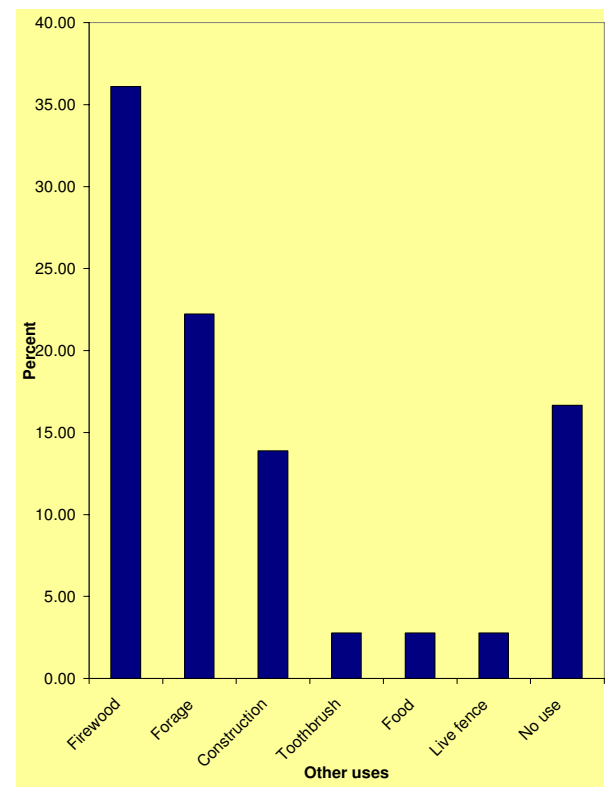

Figure 4

Added values of traditional medicinal plant species.

agricultural expansion (12.5\%) and fire (12.5\%) (Figure 5).

\section{Discussion}

The use of traditional medicinal plants to treat human ailments is not exhaustively documented in Ethiopia despite studies had been conducted in some areas of Northern [13], Northwestern [14,15], Central [16-18], Southeastern [19-21] and Southwestern [2] Ethiopia. In the current study, a total of 27 medicinal plant species in 27 genera which were used by traditional healers were recorded from four Kebeles of Sekoru District, Jimma Zone, Southwestern Ethiopia.

Result of this study showed that most of the medicinal plant species used were reported as wild. Similar studies conducted in Ethiopia [19,16,21], Uganda [22,23], Serbia [24] and in Northern Peru [25] indicated that most medicinal plant species used to treat human ailments were wild. This implies that the majority of plants of medical importance were not yet cultivated by traditional healers.
Shrubs and trees were the most represented growth forms for remedy preparations in the study area. This could be due to the fact that these growth forms are available in almost all seasons as they are relatively drought resistant and are not affected by seasonal variations [26].

Leaves were the most cited plant parts used by the healers for the preparation of traditional medicines. This finding is in line with the results of other ethnomedicinal studies in Africa $[16,27,23]$ and elsewhere $[28,29]$ who reported that leaves were the most cited plant parts used in remedy preparations.

The result of this study showed that more than one plant species were mostly used by the traditional healers to prepare a remedy for ailments. This could be attributed to the additive or synergistic effects that they could have during ailment treatment $[30,25]$. However, a study conducted in Bolivia by [28] showed that most remedies were prepared from a single medicinal plant species.

Most of the traditional healers were found to have poor knowledge on dosage and antidote while prescribing remedies to their patients and most of the remedies were reported to have no serious adverse effects except vomiting and temporary inflammations. This could be attributed to the low toxicity of the remedy preparations of the medicinal plant species used by the traditional healers in the study area [27].

The reported medicinal plants of the study area were mostly indicated to be abundant and rare. Furthermore, the abundance of medicinal plant species showed significant variation with respect to their marketability, parts used and added values. This significant variation in abundance between non-marketable and marketable medicinal plant species could be attributed to the absence of commercialization pressure, which is believed to reduce over-harvesting of non-marketable medicinal plant species in the study area. On the other hand, the significant difference observed on the abundance of the medicinal plant species with respect to plant parts used and their added values might have resulted due to the various threatening factors mainly the increased anthropogenic pressure on those medicinal plant species of the study area.

The indigenous knowledge among traditional healers with regard to their age and educational level was similar. This might be attributed to equal access of their family members to the existing indigenous knowledge regardless of age and educational level. The proportion of healers who used to transfer their knowledge and those who didn't use to transfer was also similar. This reveals that some of the traditional healers might have given much 


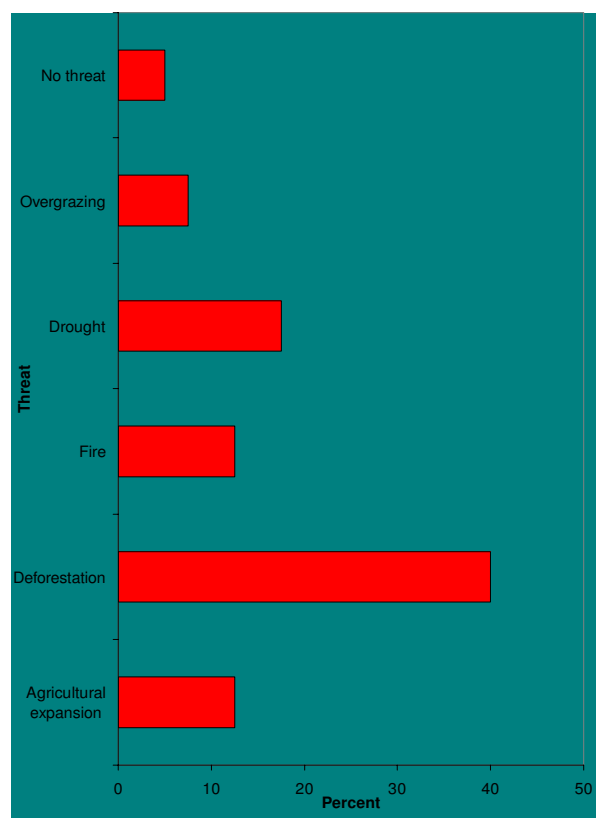

Figure 5

Reported threats to medicinal plant species of the study area.

attention to the indigenous knowledge transfer while others kept the knowledge with them for the sake of secrecy or they might have little concern regarding the value of indigenous knowledge.

According to the available literatures, some of the reported medicinal plant species were found to have some phytochemical and biological activities. Antibacterial activities were reported from the essential oil of $C$. anisata leaves [31]. This validates the reported traditional use of this species by local healers to treat Naqarsaa in the current study area. Leaf extracts of C. hirsuta was indicated to have strong antifungal activity on certain species of fungi [32]. But this medicinal plant species was reported to treat earache (Dhukuba Guraa) by traditional healers of the study area, which needs further study to confirm its antibacterial activity. In vitro test by [33] and [34] showed extracts of $C$. myricoides to have antiplasmodial activity. However, in the current study, this species was reported to treat tumor (Tanacha). The leaf extracts of E. abyssinica showed strong antiviral activity [32] and trypanocidal activity [35] in Rwanda and Uganda, respectively. Antibacterial activity of this species was also reported from East Africa [36] and this agrees with the reported use of this species by the local healers of the study area to treat gonorrhoea (Dhukuba Dhiraa). Antiviral activity from methanolic extracts of $P$. zeylanica was reported in Ethiopia [37]. But this species was reported by the traditional healers of the current study area to treat tumor (Tanachaa). Root extracts of Withania somnifera (L.) Dun showed anticarcinogenic [38,39] and anti-stress activity [40]. The latter activity of this species validates its traditional use by the local healers of the study area to treat evil eye (Buda).

\section{Conclusion}

In the present study, twenty seven plant species of medicinal importance were recorded and documented. The majority of the reported medicinal plant species were wild. Many medicinal plant species were also reported to be rare. These demand an urgent attention to conserve such vital resources so as to optimize their use in the primary healthcare system. A rich heritage of indigenous medicinal plant use and knowledge was also recognized. However, awareness creation should be made among the healers so as to avoid erosion of the indigenous knowledge and to ensure its sustainable use and conservation as indigenous knowledge transfer in the study area was oral and some healers were not transferring it all. Further phytochemical and biological activity studies should also be conducted on the reported medicinal plant species of the study area so as to utilize them in drug development.

\section{Competing interests}

The author(s) declare that they have no competing interests.

\section{Authors' contributions}

Both authors contributed equally during the field work, data management and preparation of the manuscript.

\section{Additional material}

\section{Additional File 1}

List of medicinal plant species, parts used, methods of preparation, administration and diseases treated. The additional file lists plant family name, scientific name, vernacular name, specimen collection number, diseases treated, plant part used, methods of preparation and route of administration.

Click here for file

[http://www.biomedcentral.com/content/supplementary/17464269-3-24-S1.pdf]

\section{Acknowledgements}

This study was financed by the Research and Publications Office of Jimma University, Ethiopia. The authors are grateful to Mr. Ermias Lulekal and Mr. Melaku Wondafrash of the National Herbarium (ETH), Addis Ababa University for their assistance in plant species identification. Traditional healers of the study area are truly acknowledged for sharing their accumulated indigenous knowledge. We are grateful to Mr. Endaweke Assegid for con- 
structing map of the study area. We thank two anonymous referees for their critical comments. We also thank Mr. Nuru Haji Hassen who assisted us in translation during the interview process. The community health workers of the study area are truly acknowledged in coordinating the traditional healers and assisting the field work.

\section{References}

I. Kebebew F, Addis G: Utilization and conservation of medicinal plants in Ethiopia. In Proceedings of the workshop on Development and Utilization of Herbal Remedies in Ethiopia: Addis Ababa Edited by: Abebe D. Ethiopian Health and Nutrition Institute; 1996:46-52.

2. Abbink J: Medicinal and ritual plants of the Ethiopian Southwest: an account of recent research. Indigenous knowledge and Development Monitor 1995, 3:6-8.

3. Cunningham AB: Applied ethnobotany: People, wild plant use and conservation London and Sterling, VA: Earthscan Publications Ltd; $200 \mathrm{I}$.

4. Abebe D, Ayehu A: Medicinal plants and enigmatic health practices of Northern Ethiopia Addis Ababa: B.S.P.E. 1993.

5. Martin GJ: Ethnobotany: a methods manual London, UK: Chapman and Hall; 1995.

6. Flora of Ethiopia and Eritrea. Volume 3. Pittosporaceae to Araliaceae. Edited by: Hedberg I, Edwards S. The National Herbarium, Addis Ababa, Ethiopia, and Department of Systematic Botany, Uppsala, Sweden; 1989.

7. Flora of Ethiopia and Eritrea. Volume 7. Poaceae. Edited by: Hedberg I, Edwards S. The National Herbarium, Addis Ababa, Ethiopia, and Department of Systematic Botany, Uppsala, Sweden; 1995.

8. Flora of Ethiopia and Eritrea. Volume 2, part 2. Canellaceae to Euphorbiaceae. Edited by: Edwards S, Tadesse M, Hedberg I. The National Herbarium, Addis Ababa, Ethiopia, and Department of Systematic Botany, Uppsala, Sweden;; 1995.

9. Flora of Ethiopia and Eritrea. Volume 6. Hydrocharitaceae to Arecaceae. Edited by: Edwards S, Demissew S, Hedberg I. The National Herbarium, Addis Ababa, Ethiopia, and Department of Systematic Botany, Uppsala, Sweden; 1997.

10. Flora of Ethiopia and Eritrea. Volume 2, part I. Magnoliaceae to Flacourtiaceae. Edited by: Edwards S, Tadesse M, Demissew S Hedberg I. The National Herbarium, Addis Ababa, Ethiopia, and Department of Systematic Botany, Uppsala, Sweden; 2000.

II. Flora of Ethiopia and Eritrea. Volume 4, part I. Apiaceae to Dipsacaceae. Edited by: Hedberg I, Edwards S, Nemomissa S. The National Herbarium, Addis Ababa, Ethiopia, and Department of Systematic Botany, Uppsala, Sweden; 2003.

12. Flora of Ethiopia and Eritrea. Volume 4, part 2. Asteraceae. Edited by: Hedberg I, Friis I, Edwards S. The National Herbarium, Addis Ababa, Ethiopia, and Department of Systematic Botany, Uppsala, Sweden; 2004.

13. Abebe $W$ : Traditional pharmaceutical practice in gondar region, northwestern Ethiopia. Journal of Ethnopharmacology 1984, I I:33-47.

14. Teklehaymanot T, Giday M: Ethnobotanical study of medicinal plants used by people in Zegie Peninsula, Northwestern Ethiopia. Journal of Ethnobiology and Ethnomedicine 2007, 3:I2.

15. Giday M, Teklehaymanot $T$, Animut A, Mekonnen $Y$ : Medicinal plants of the Shinasha, Agew-awi and Amhara peoples in northwest Ethiopia. Journal of Ethnopharmacology 2007, I 1 0:516-525.

16. Giday M, Asfaw Z, Elmqvist T, Woldu Z: An ethnobotanical study of medicinal plants used by the Zay people in Ethiopia. Journal of Ethnopharmacology 2003, 85:43-52.

17. Gedif $T$, Hahn HJ: The use of medicinal plants in self-care in rural central Ethiopia. Journal of Ethnopharmacology 2003, 87:|155-|6I.

18. Teklehaymanot T, Giday M, Medhin G, Mekonnen Y: Knowledge and use of medicinal plants by people around Debre Libanos monastery in Ethiopia. Journal of Ethnopharmacology 2007, I I I:27 I-283.

19. Addis G, Abebe D, Urga K: A survey of traditional medicina plants in Shirka District, Arsi Zone, Ethiopia. Ethiopian Pharmaceutical Journal 200I, 19:30-47.

20. Addis G, Abebe D, Genebo T, Urga K: Perceptions and practices of modern and traditional health practitioners about traditional medicine in Shirka District, Arsi Zone, Ethiopia. Ethiopian Journal of Health Development 2002, 16:19-29.

21. Wondimu T, Asfaw Z, Kelbessa E: Ethnobotanical study of medicinal plants around 'Dheeraa' town, Arsi Zone, Ethiopia. Journal of Ethnopharmacology 2007, I | 2: | 52-161.

22. Tabuti JRS, Lye KA, Dhillion SS: Traditional herbal drugs of Bulamogi, Uganda: plants, use and administration. Journal of Ethnopharmacology 2003, 88:19-44.
23. Kamatenesi-Mugisha $\mathrm{M}$, Oryem-Origa $\mathrm{H}$ : Medicinal plants used to induce labour during childbirth in western Uganda. Journal of Ethnopharmacology 2007, 109: I-9.

24. Jariæ S, Popoviæ Z, Maèukanoviæ-Jociæ M, Djurdjeviæ L, Mijatoviæ M, Karadžiæ B, Mitroviæ M, Pavloviæ P: An ethnobotanical study on the usage of wild medicinal herbs from Kopaonik Mountain (Central Serbia). Journal of Ethnopharmacology 2007, I I I: I60-175.

25. Bussman RW, Sharon D: Traditional medicinal plant use in Northern Peru: tracking two thousand years of healing culture. Journal of Ethnobiology and Ethnomedicine 2006, 2:47.

26. Albuquerque UP: Re-examining hypothesis concerning the use and knowledge of medicinal plants: a study in the Caatinga vegetation of NE Brazil. Journal of Ethnobiology and Ethnomedicine 2006, 2:30.

27. Togola A, Diallo D, Dembélé S, Barsett H, Paulsen BS: Ethnopharmacological survey of different uses of seven medicinal plants from Mali, (West Africa) in the regions Doila, Kolokani and Siby. Journal of Ethnobiology and Ethnomedicine 2005, I:7.

28. Macía MJ, García E, Vidaurre PJ: An ethnobotanical survey of medicinal plants commercialized in the markets of $\mathbf{L a} \mathbf{P a z}$ and EI Alto, Bolivia. Journal of Ethnopharmacology 2005, 97:337-350.

29. Almeida CFC, de Amorim ELC, de Albuquerque UP, Maia MBS: Medicinal plants popularly used in the $X$ ingü region - a semiarid location in Northeastern Brazil. Journal of Ethnobiology and Ethnomedicine 2006, 2:I5.

30. Igoli JO, Tor-Anyiin TA, Usman SS, Oluma HOA, Igoli NP: Folk medicines of the lower Benue valley of Nigeria. In Recent Progress in Medicinal Plants Edited by: Singh VK, Govil JN, Hashmi S, Singh G. USA: Sci. Tech. Pub; 2002:327-338. Govil JN and Singh VK (Series Editors) Ethnomedicine and Pharmacognosy, vol 7

31. Gundidza M, Chinyanganya F, Chagonda L, De Pooter HL, Mavi S: Phytoconstituents and antimicrobial activity of the leaf essential oil of clausena anisata (Willd.) J.D. Hook ex. Benth. Flavor and Fragrance Journal 1994, 9:299-303.

32. Cos P, Hermans N, De Bruyne T, Apers S, Sindambiwe JB, Berghe DV Pieters L, Vlietinck AJ: Further evaluation of Rwandan medicinal plant extracts for their antimicrobial and antiviral activities. Journal of Ethnopharmacology 2002, 79:155-163.

33. Muregi FW, Chhabra SC, Njagi ENM, Lang'at-Thoruwa CC, Njue WM, Orago ASS, Omar SA, Ndiege IO: Anti-plasmodial activity of some Kenyan medicinal plant extracts singly and in combination with chloroquine. Phytotherapy Research 2004, 1 8:379-384.

34. Muregi FW, Ishih A, Miyase T, Suzuki T, Kino H, Amano T, Mkoji GM Terada M: Antimalarial activity of methanolic extracts from plants used in Kenyan ethnomedicine and their interactions with chloroquine (CQ) against a CQ-tolerant rodent parasite, in mice. Journal of Ethnopharmacology 2007, I I I : I90- 195.

35. Freiburghaus F, Steck A, Pfander H, Brun R: Bioassay-guided isolation of a diastereoisomer of kolavenol from Entada abyssinica active on Trypanosoma brucei rhodesiense. Journal of Ethnopharmacology 1998, 61:179-183.

36. Fabry W, Okemo PO, Ansorg R: Antibacterial activity of East African medicinal plants. Journal of Ethnopharmacology 1998, 60:79-84.

37. Gebre-Mariam T, Neubert R, Schmidt PC, Wutzler P, Schmidtke M: Antiviral activities of some Ethiopian medicinal plants used for the treatment of dermatological disorders. Journal of Ethnopharmacology 2006, 104:182-187.

38. Christina AJM, Joseph DG, Packialakshmi M, Kothai R, Robert SJH, Chidambaranathan N, Ramasamy M: Anticarcinogenic activity of Withania somnifera Dunal against Dalton's Ascitic Lymphoma. Journal of Ethnopharmacology 2004, 93:359-36I.

39. Mathur R, Gupta SK, Singh N, Mathur S, Kochupillai V, Velpandian T: Evaluation of the effect of Withania somnifera root extracts on cell cycle and angiogenesis. Journal of Ethnopharmacology 2006, 105:336-341.

40. Bhattacharya A, Ghosal S, Bhattacharya SK: Anti-oxidant effect of Withania somnifera glycowithanolides in chronic footshock stress-induced perturbations of oxidative free radical scavenging enzymes and lipid peroxidation in rat frontal cortex and striatum. Journal of Ethnopharmacology 200I, 74:1-6. 